\title{
Introducing the Special Issue 22.3 Rethinking the Legacy of the League of Nations
}

\author{
Rossana Deplano \\ Lecturer and Deputy Director, Centre for European Law and \\ Internationalisation, University of Leicester, Leicester, UK \\ rd279@leicester.ac.uk
}

A legacy is a factual and historical account of something that has had a lasting impact on the present. The League of Nations has proved to be a milestone in the development of the international community: it shaped central features of international law today. Therefore, appraising the League of Nations and its legacies sheds light on the strengths and shortcomings of the contemporary international legal system. This special issue is inspired by and reflects some of the issues discussed at the conference marking the centennial of the creation of the League of Nations (1919) hosted by the Centre for European Law and Internationalisation of the University of Leicester on 31 January 2019. ${ }^{1}$

Jean d'Aspremont reflects on scholarly narratives that construct the League of Nations as an experiment which emerged since the second half of the twentieth century to assess the significance of the League of Nations in the history of international organization and international law. Reconstructing the conceptual categories of scholarly narratives about the League of Nations as an experiment in international law, he argues:

'Experiment narratives' in international law constitute a convenient tool for international lawyers to uphold a progressive and linear global history and to organize their discourses on international institutional law, collective security and international institutions. ${ }^{2}$

1 The conference was generously supported by the Society of Legal Scholars.

2 J d'Aspremont, 'The League of Nations and the Power of 'Experiment Narratives' in International Institutional Law' at 275-29o. 
International lawyers appear to have developed different types of experiment narratives, each narrative providing a window to our understanding of the contributions (including the missing ones) of the League of Nations to the development of specific areas of international law. Experiment narratives also serve an introspective function aimed at shedding light on the ways in which scholars construe their discourses about the League of Nations and international law in general.

The three further contributions in this special issue illustrate the variety of types of experiment narratives. Each contribution focuses on different aspects of the significance of the League of Nations for the development of international law and institutions, thus imparting a different perspective to it as an experiment in international law.

Nicholas Tsagourias examines the League of Nations as the institutional realization of a political project of world order based on law rather than force. He treats the League of Nations as an experiment of global order informed by past trajectories and imbued with new thinking, one that has laid down the governance institutions of global order. This allows him to study its failures as well as its contributions to a novel vision of world order constructed around the United Nations and beyond. His article points to the continuity between past and present, thus attributing formative merit to the League of Nations as an experiment in world order.

Nigel White evaluates the constitutional character of the collective security system envisaged by the Covenant of the League of Nations as opposed to the system collective security established by the Charter of the United Nations. By focusing on the composition and functioning, both in theory and in practice, of the two organs in charge of maintaining the peace of the world by providing collective security arrangements - namely, the Council of the League of Nations and the United Nations Security Council - he concludes that the League of Nations was a less effective, yet morally superior type of institutional arrangement. Although there is some continuity between the past and the present systems of collective security, White concludes that the current system of collective security under the United Nations has somehow lost the ability to achieve real peace through law. In this respect, the idealism and moral character enmeshed in the provisions of the Covenant of the League of Nations is superior to the elements of realpolitik underpinning the collective security provisions of the UN Charter.

Finally, Antal Berkes examines the contribution of the League of Nations to the development of international law. By focusing on the law of state responsibility, he reconstructs the work of the conference convened under the auspices of the League of Nations in The Hague between 1924 and 1930, showing that 
the legal principles elaborated therein effectively form the intellectual background of the work of the United Nations International Law Commission leading to the adoption of the Articles on Responsibility of States for Internationally Wrongful Acts (2001). In doing so, the article informs our knowledge and understanding of the formative role of the League of Nations in the codification and progressive development of a particular area of international law.

The contributions to this special issue focus on comparisons between past and present world orders, especially drawing on the relationship between the League of Nations and the United Nations. However, how much of the League of Nations has been transposed (or not) into the United Nations is difficult to determine. Instead, what is clear is that the formative stages of the Covenant of the League of Nations and the Charter of the United Nations share a history of personal leadership on the part of those shaping the process of restructuring international organization and of ideology, whose combination eventually led to the production of two different documents embedded with different types of idealisms. On the one hand, US President Woodrow Wilson wanted to create an international organization governed by morality and state self-restraint in international relations. Viewed from this angle, idealism and the rule of law converge. Wilson's resolve and determination were so strong that historians Hoopes and Brinkley describe it as 'moral and intellectual arrogance. ${ }^{3}$ As is well known, the League of Nations succumbed to the radical ideology of nationalism heralded by individual states.

On the other hand, the history of the UN Charter is inextricably linked to the post-war projects of US President Franklin Roosevelt, UK Prime Minister Winston Churchill and Marshal Stalin of the Soviet Union. Three different personalities with different cultural background and ideologies found themselves allied in the effort of bringing World War Two to a close by defeating the Axis powers. They all firmly opposed the continuation of the League of Nations, which was seen as an ineffective institution. At the same time, they planned essentially to create a peacekeeping organization guided by a dominant executive organ in which the Allied powers were granted a permanent seat and veto power over decisions involving the use of military force. ${ }^{4}$ Extensive compromise had to be found to reconcile the US request that the scope of the organization covered the root causes of war as well (namely, economic and social conditions), the British demands for the new trusteeship system

3 T Hoopes and D Brinkley, FDR and the Creation of the U.N. (1997), 2.

4 For a US perspective on the history of the UN Charter, see TM Campbell, Masquerade Peace: America's UN Policy, 1944-1945 (1973); RB Russell, A History of the United Nations Charter: The Role of the United States, 1940-1945 (1958). 
that did not put at risk the very existence of the British empire and the Soviet Union's request for control over Eastern Europe. ${ }^{5}$ As a result, the drafting history of the UN Charter is a blend of ideological premises often in conflict with each other. The result is that the final text adopted in San Francisco in 1945 lacks coherence.

The biggest legacy of the League of Nations and, at the same time, the lesson not learnt from its short-lived experience is how political (and moral) idealism can shape the outcome of the process of determining the conduct of international relations, which unavoidably accommodates short and long term compromises between international actors. And compromise, in turn, brings disillusionment. Political compromise reverberates through international law as well, thus creating shades of international legality oscillating between morality and opportunism against a backdrop of realpolitik. This is most evident in the structure and functioning of the current system of collective security. As Nigel Whites notes in his article, eventually the morality of the Covenant of the League of Nations has had to succumb to the expediency of action of the UN Charter - all, of course, in the name of law.

\section{Note}

Rossana Deplano is the guest editor of this special issue with Professor Nicholas Tsagourias (University of Sheffield, UK) and Professor Katja Ziegler (University of Leicester, UK).

5 For a detailed reconstruction of the three positions, see Hoopes and Brinkley (n 3), $26 \mathrm{ff}$; RC Hilderbrand, Dumbarton Oaks: The Origins of the United Nations and the Search for Postwar Security (1990), 85-107 (focus on the Dumbarton Oaks conversations). 